\title{
Methane from Human Excreta: Comparative Assessment of Batch and Continuous Biomethanation Process
}

\author{
Surendra N. Gohil ${ }^{1 *}$, Prateek G. Shilpkar ${ }^{2}$, Mayur C. Shah², Amitkumar J. Shah ${ }^{2}$ \\ and Pradip B. Acharya ${ }^{3}$
}

1,2Biogas Research Centre and Department of Microbiology, Gujarat Vidyapith, Sadra, Gandhinagar, Gujarat, India. India. ${ }^{3}$ I/C Ex-HOD, Biogas Research Centre and Department of Microbiology, Gujarat Vidyapith, Sadra, Gandhinagar, Gujarat, India.

\begin{abstract}
Treatment of human excreta (HE) is necessary before its discharge into natural water body. Untreated discharge may cause several ill effects for environment and human health. Anaerobic digestion of human excreta can unravel this problem along with production of biogas. Anaerobic digestion process may be either batch type or continuous type. In present study, human excreta were degraded anaerobically by both the means in the laboratory scale $5 \mathrm{~L}$ capacity glass digesters. The comparative assessment between batch digestion and continuous digestion was carried out. The digesters were fed with human excreta at $6 \%$ Total Solids and operated at ambient temperature of $20-37^{\circ} \mathrm{C}$ for 99 days. The results show that average biogas production in batch feeding process is $322.78 \mathrm{mLday}^{-1}$ whereas in continues digestion it is $382 \mathrm{mLday}^{-1}$. Total biogas production during 99 days in batch digestion and continue digestion is $31955.1 \mathrm{~mL}$ and $37833.9 \mathrm{~mL}$ respectively. Average methane content in biogas produced in continuous and batch digestion was $68.0 \%$ and $67.4 \%$ respectively. Results conclude that human excreta can be successfully digested anaerobically to produce biogas with good methane content either by batch or continuous digestion process.
\end{abstract}

Keywords: Methane, human excreta, biogas, renewable energy.

*Correspondence: surendra@gujaratvidyapith.org

(Received: 03 September 2018; accepted: 16 October 2018)

Citation: Surendra N Gohil, Prateek G Shilpkar, Mayur C Shah, Amitkumar J Shah, Pradip B Acharya, Methane from Human Excreta: Comparative Assessment of Batch and Continuous Biomethanation Process , J Pure Appl Microbiol., 2018; 12(4):2143-2148. http://dx.doi.org/10.22207/JPAM.12.4.52

(c) The Author(s) 2018. Open Access. This article is distributed under the terms of the Creative Commons Attribution 4.0 International License which permits unrestricted use, sharing, distribution, and reproduction in any medium, provided you give appropriate credit to the original author(s) and the source, provide a link to the Creative Commons license, and indicate if changes were made. 


\section{INTRODUCTION}

The global population is expected to grow by about $35 \%$ by 2050 (UN, 2013), will increase challenges for treatment of various types of organic wastes generated by humans. Human excreta (HE) are one of them. Recycling and reuse of these wastes may be the only way to resolve this problem. Biomethanation of HE may be a useful way to recycle it. Biomethanation is a natural process operated in anaerobic conditions through the activities of microorganisms that utilize organic wastes and produce biogas and fertilizer. This paper seeks to comparative assessments of the biogas production from HE by two ways i.e. batch and continuous digestion process.

\section{MATERIALS AND METHODS Experimental set-up}

Total six experimental sets were used, three each for batch digestion and continuous digestion. One experimental set contains three glass bottles, one (5.0L capacity) digester bottle, one (2.0L capacity) gas holder and another one (2.0L capacity) water replacement bottle. 5.0L digester bottle had an outlet at $4800 \mathrm{~mL}$. Feeding assembly was provided for daily feeding which maintain the feeding level at $4800 \mathrm{~mL}$. Produced gas was allowed to escape from the top of digester to enter in a $2.0 \mathrm{~L}$ graduated gas holder bottle which coupled with water displacement bottle, containing acidified colored water. The acidified colored water contains $10 \% \mathrm{NaCl}$ and $\mathrm{K}_{2} \mathrm{Cr}_{2} \mathrm{O}_{7}$ $(0.1 \mathrm{~g} \%)$ and this solution was acidified with $\mathrm{H}_{2} \mathrm{SO}_{4}$ (pH $2-4)$.

\section{Gas production measurement}

A scale was pasted at outer surface of gas holder bottle to measure the gas production accurately. In the gas holder bottle the level of acidified colored water was set daily at zero on pasted scale. Gas holder bottle remains connected with digester at one end and with water displacement bottle at another end. When the gas was produced in digester enter into gas holder bottle it pressurized the water level in it being set at zero. Corresponding to the pressure of produced gas the water level in gas holder bottle goes down and simultaneously the water level in water displacement bottles rises. The difference in final and initial level of water in gas holder bottle gives the amount of produced biogas.

\section{Feeding and Inoculum}

In batch digesters the HE slurry was fed to its working volume of $4800 \mathrm{~mL}$ maintaining the total solids contents at $6 \%$. In continuous digester $120 \mathrm{~mL}$ of human excreta (at $6 \%$ Total Solids) was added per day upto 40 days to fill it at its working volume of $4800 \mathrm{~mL}$. To start the biomethanation process anaerobically digested slurry from running Biogas plant of our institution was added in all the digesters @10\% (v/v) as an inoculum.

\section{Analysis of methane in biogas}

The methane content in produced biogas was measured frequently by orsat apparatus.

\section{RESULTS AND DISCUSSIONS}

Data presented in Table-1 show that the biogas production in batch digester starts from $2^{\text {nd }}$ day but its amount was quite low as $26.2 \mathrm{~mL}$ only which suddenly jumped to $235.8 \mathrm{~mL}$ on $4^{\text {th }}$ day and thereafter it remained between 235.8 and $262.0 \mathrm{~mL}$ from $4^{\text {th }}$ to $6^{\text {th }}$ day. From $7^{\text {th }}$ to $10^{\text {th }}$ day biogas production further increased and remained between 432.3 and $524.0 \mathrm{~mL}$. From $11^{\text {th }}$ to $24^{\text {th }}$ day biogas production varies between a minimum value of $602.6 \mathrm{~mL}$ and a maximum value of $681.2 \mathrm{~mL}$ except $12^{\text {th }}$ day $(550.0 \mathrm{~mL})$ and $16^{\text {th }}$ day $(563.3 \mathrm{~mL})$. This is the period in batch digester when highest biogas production was obtained. From $25^{\text {th }}$ day onwards biogas production decreases continuously. It ranged between 510.9 to $576.4 \mathrm{~mL}$ between $25^{\text {th }}$ and $31^{\text {st }}$ day, except $29^{\text {th }}$ day $(495.0 \mathrm{~mL}) ; 406.1$ and $497.8 \mathrm{~mL}$ between $32^{\text {nd }}$ and $50^{\text {th }}$ day, except $36^{\text {th }}$ day $(537.1 \mathrm{~mL}), 37^{\text {th }}$ day $(510.90 \mathrm{~mL})$ and $40^{\text {th }}$ day $(524.0 \mathrm{~mL}) ; 327.5$ and $366.8 \mathrm{~mL}$ between 51 th and $67^{\text {th }}$ day, except 53th day $(419.2 \mathrm{~mL})$; and 235.8 and $288.2 \mathrm{~mL}$ between $68^{\text {th }}$ and $80^{\text {th }}$ day, except $78^{\text {th }}$ day $(91.7 \mathrm{~mL})$. Data show that after $80^{\text {th }}$ day biogas production in batch digester remains below $100 \mathrm{~mL}$ and decreases continuously till 99 days and reaches to a minimum value of $13.1 \mathrm{~mL}$. Data of biogas production in batch digester show that there is continuous increase in biogas production till a peak is reached and then it decreases continuously, due to reduction of nutrients in digester may produce starvation condition therefor methenogesis process undergoes decrease. Similar trend was observed previously ${ }^{2}$.

This trend did not observe for biogas production in continuous digester. Here, biogas 
Gohil et al. J Pure Appl Microbiol, 12(4), 2143-2148 | Dec. 2018 | http://dx.doi.org/10.22207/JPAM.12.4.52

Table 1. Daily production of biogas in continuous and batch digester throughout the experimentation period

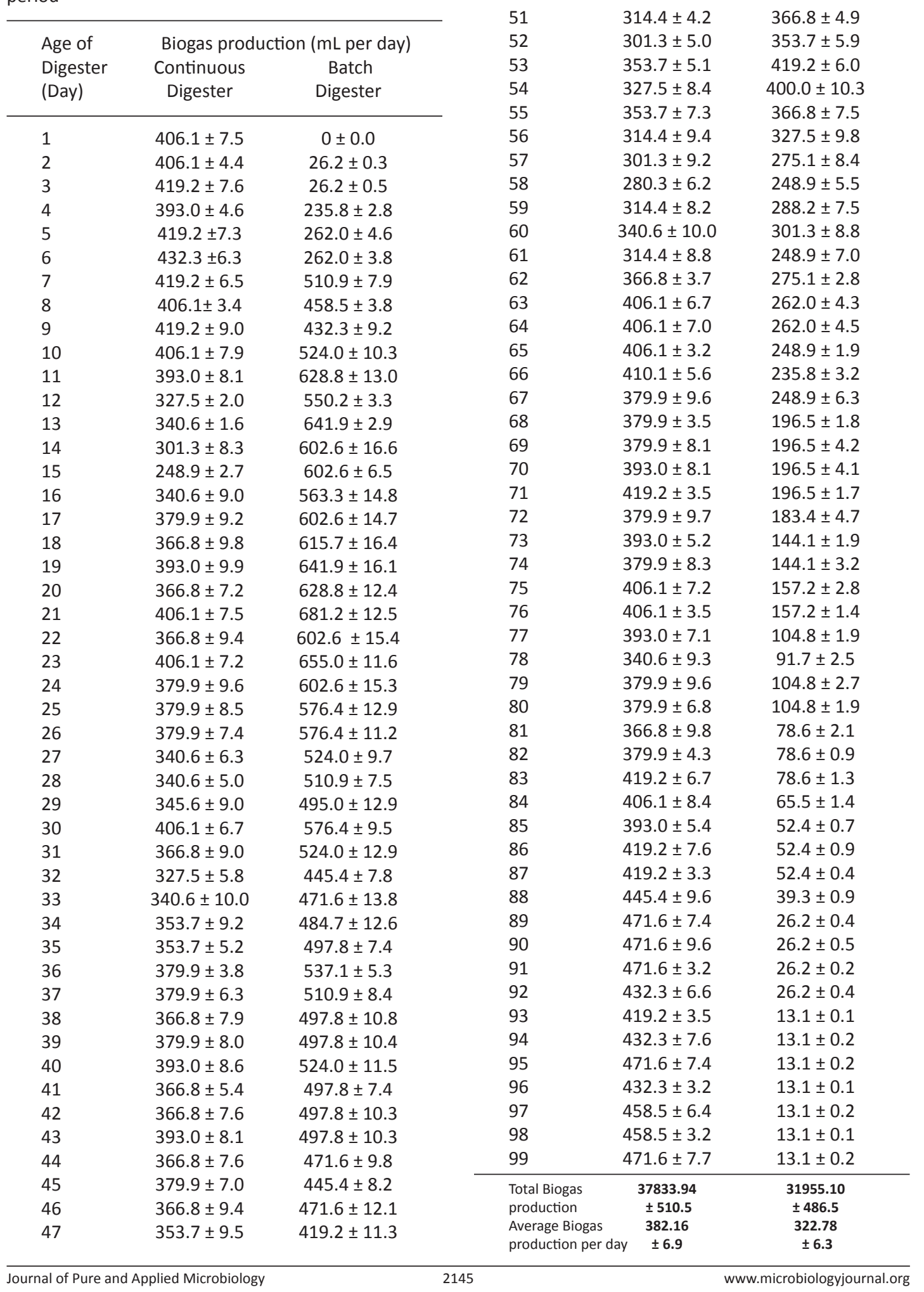

$366.8 \pm 7.5 \quad 419.2 \pm 8.5$

$353.7 \pm 6.1-419.2 \pm 7.2$

$314.4 \pm 4.2 \quad 366.8 \pm 4.9$

$301.3 \pm 5.0 \quad 353.7 \pm 5.9$

$19.2 \pm 6.0$

$314.4 \pm 9.4$

$314.4 \pm 8.2 \quad 288.2 \pm 7.5$

$366.8+3.7-275.1 \pm 2.8$

$196.5 \pm 4.2$

$4 \pm 4.7$

$57.2 \pm 2.8$

$91.7 \pm 2.5$

$104.8 \pm 2.7$

$78.6 \pm 0.9$

$52.4 \pm 0.7$

$26.2 \pm 0.2$

$13.1 \pm 0.2$

$13.1 \pm 0.1$

$13.1 \pm 0.1$
$379.9 \pm 9.6 \quad 406.1 \pm 10.3$ 
production ranged between 406.1 and $432.3 \mathrm{~mL}$ from $1^{\text {st }}$ to $10^{\text {th }}$ day, except on $4^{\text {th }}$ day $(393.0 \mathrm{~mL})$. It should be noted here that $1^{\text {st }}$ day of continuous digester refers to the day after it is being filled at $4800 \mathrm{~mL}$ (actual $41^{\text {st }}$ day of experimentation and so on). Thereafter between $11^{\text {th }}$ to $62^{\text {th }}$ day biogas production decreases and ranged between 301.3 and $393.0 \mathrm{~mL}$, except on $15^{\text {th }}$ day $(248.9 \mathrm{~mL})$, $21^{\text {st }}, 23^{\text {rd }}$ and $30^{\text {th }}$ day $(406.1 \mathrm{~mL})$ and $58^{\text {th }}$ day $(280.34 \mathrm{~mL})$. From 63 to $66^{\text {th }}$ day, biogas production further increased and ranged between 406.1 and $410.1 \mathrm{~mL}$. From $67^{\text {th }}$ day biogas production further decreases and ranged between 340.6 and $393.0 \mathrm{~mL}$ between $67^{\text {th }}$ and $82^{\text {nd }}$ day except 71th day $(419.2 \mathrm{~mL})$ and 75 and $76^{\text {th }}$ day $(406.10 \mathrm{~mL})$.
From $83^{\text {rd }}$ day onwards biogas production again increases and ranged between 406.1 and $471.6 \mathrm{~mL}$ between 83rd and 99th day, except 85th day $(393.0 \mathrm{~mL})$. With respect to batch digestion continuous digestion system getting nutrients on daily basis therefor methanogenesis process didn't disturbed and biogas production remain near to constant rate. Similar trend was observed previously in a continues anaerobic digestion study $^{3}$.

Total biogas production during the experimentation period of 99 days was recorded as $37833.94 \mathrm{~mL}$ in continuous digester with average of $382.16 \mathrm{~mL}$ per day and as $31955.1 \mathrm{~mL}$ in batch digester with and an average of $322.78 \mathrm{~mL}$ per day.

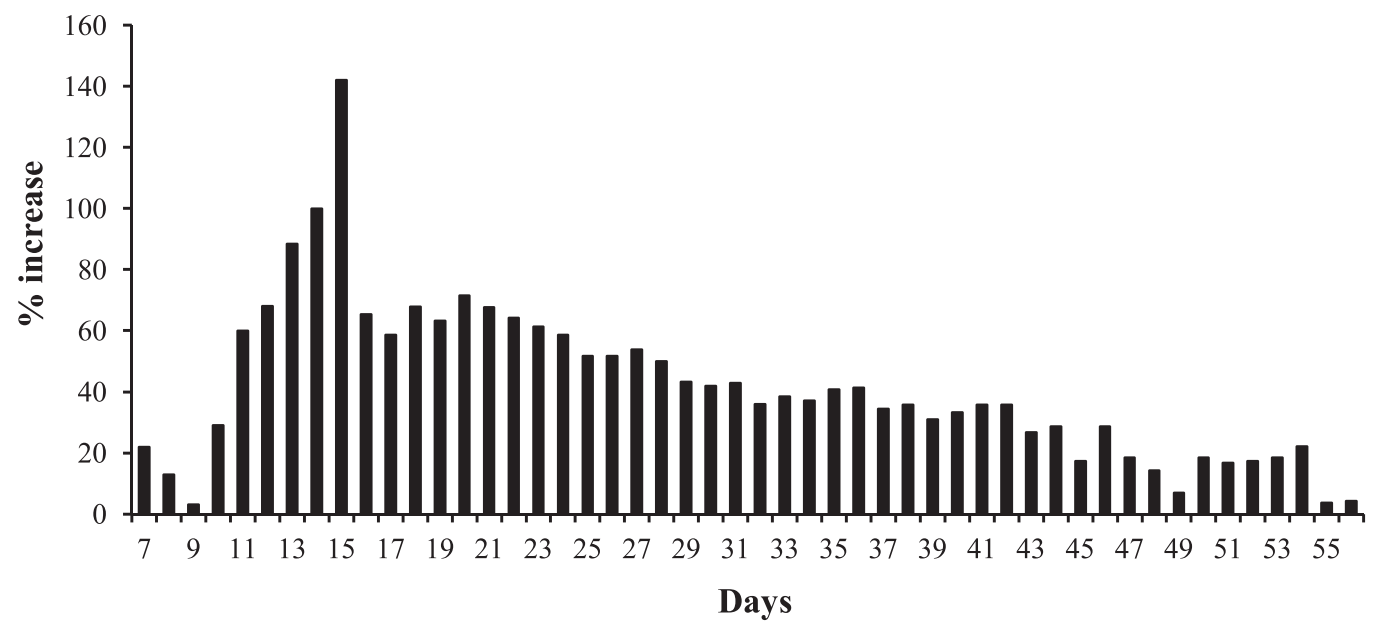

Fig. 1. Percentage increase in Biogas production in Batch Digester over Continuous Digester

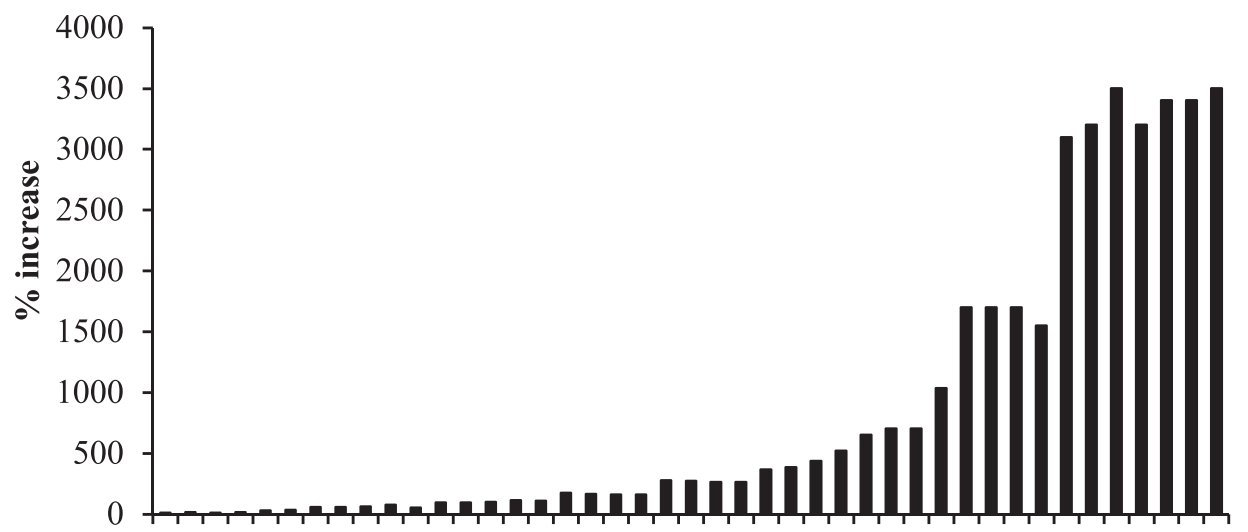

$\begin{array}{llllllllllllllllllllll}57 & 59 & 61 & 63 & 65 & 67 & 69 & 71 & 73 & 75 & 77 & 79 & 81 & 83 & 85 & 87 & 89 & 91 & 93 & 95 & 97 & 99\end{array}$

Days

Fig. 2. Percentage increase in Biogas production in Batch Digester over Continuous Digester 
A close observation of Data presented in Table-1 reveals that the biogas production was higher in batch digester compared to continuous digester from Day $7^{\text {th }}$ to $56^{\text {th }}$ (Fig.1). Whereas, from $57^{\text {th }}$ day to 99 th day reverse trend was observed and biogas production shows its higher value in continuous digester compared to batch one (Fig. 2). Effectiveness of batch digestion process over continues digestion process in earlier stage of digestion was reported ${ }^{3}$ using Mathematical Models for Comparative Evaluation of Batch and Continuous Anaerobic Digesters.

\section{Biogas production and Temperature}

Data presented in Fig. 3 reveals that biogas production in batch digester has no relation with increase or decrease in average temperature value. Results conclude that the biogas production is affected by some other factors than temperature.

On the other hand, production of biogas in continuous digester follows the path of rise and fall in average temperature (Fig. 4).

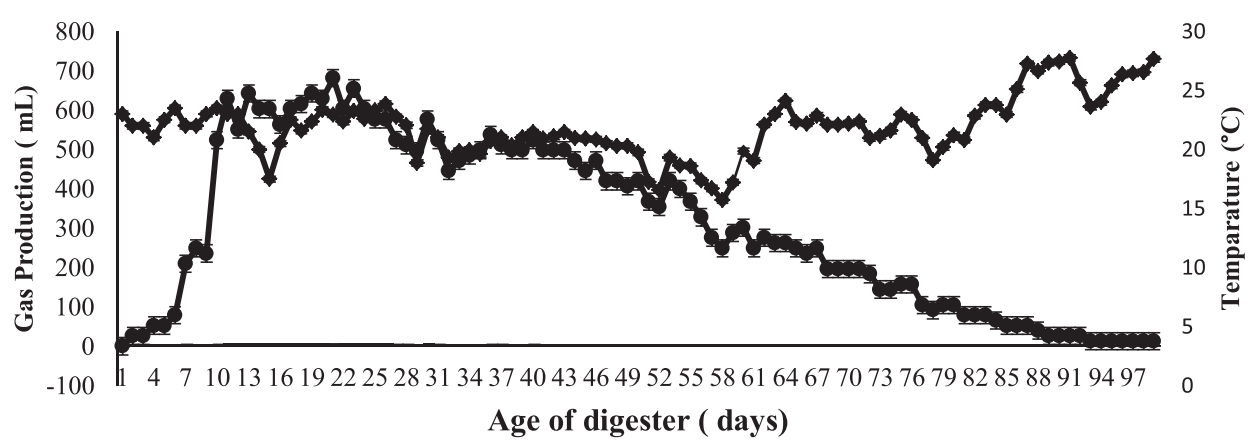

$\longrightarrow$ Gas Production $(\mathrm{mL}) \longrightarrow$ Average Temp.

Fig. 3. Effect of average temperature on Biogas production in batch digester

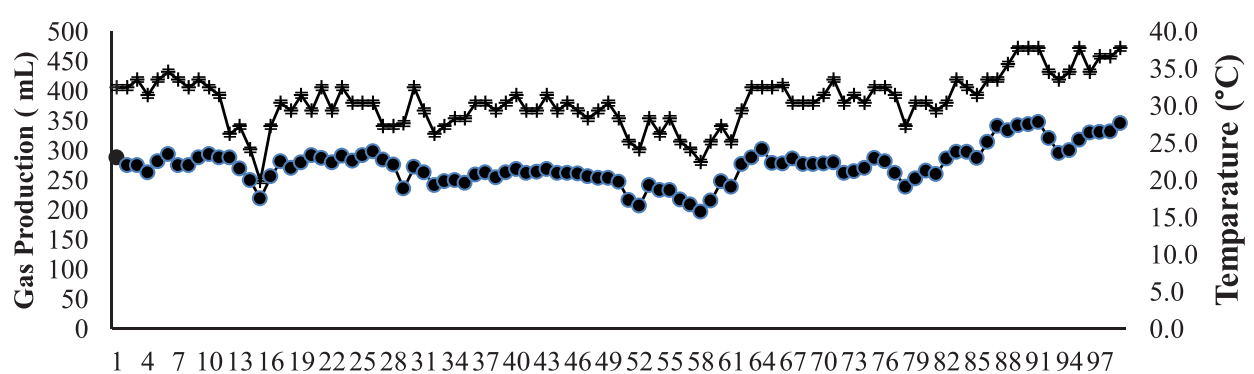

Age of digester ( days)

$\longrightarrow$ Gas Productio $(\mathrm{mL}) \quad \longrightarrow$ Average Temparature

Fig. 4. Effect of average temperature on Biogas production in continuous digester

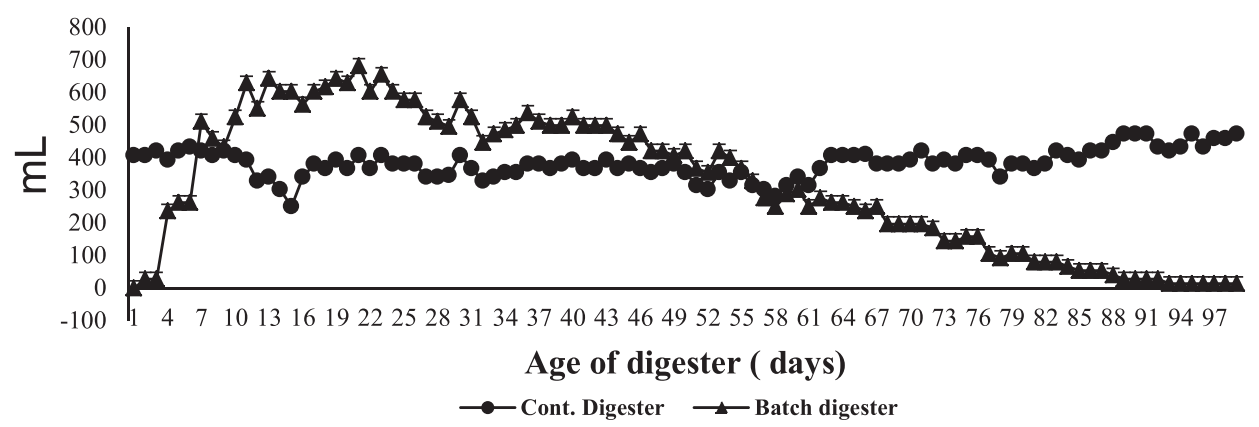

Fig. 5. Comparative biogas production in Continuous and Batch digester 
Table 2. Methane content (\%) in produced biogas in continuous and batch digestion process (\%)

\begin{tabular}{|c|c|c|c|}
\hline \multicolumn{2}{|c|}{ Continuous Digester } & \multicolumn{2}{|c|}{ Batch Digester } \\
\hline $\begin{array}{l}\text { Age of } \\
\text { Digester } \\
\text { (Day) }\end{array}$ & $\begin{array}{l}\text { Methane } \\
(\%)\end{array}$ & $\begin{array}{l}\text { Age of } \\
\text { Digester } \\
\text { (Day) }\end{array}$ & $\begin{array}{l}\text { Methane } \\
(\%)\end{array}$ \\
\hline 55 & $60.2 \pm 0.6$ & 15 & $40.3 \pm 0.4$ \\
\hline 70 & $66.0 \pm 1.2$ & 30 & $58.8 \pm 1.1$ \\
\hline 85 & $70.2 \pm 0.8$ & 45 & $68.3 \pm 0.8$ \\
\hline 100 & $70.8 \pm 1.2$ & 60 & $78.1 \pm 1.4$ \\
\hline 115 & $70.1 \pm 1.0$ & 75 & $78.2 \pm 1.1$ \\
\hline 130 & $70.5 \pm 1.1$ & 90 & $80.5 \pm 1.2$ \\
\hline Average & & Average & \\
\hline Methane & $68.0 \pm 1.0$ & Methane & $67.4 \pm 1.2$ \\
\hline
\end{tabular}

Comparison of produced biogas in continuous and batch digestion clearly reveals that in continuous digester a steady amount of biogas is generated (minimum $248.9 \mathrm{~mL}$ and maximum $471.6 \mathrm{~mL}$ ) whereas in batch digester production of biogas varies greatly (minimum 26.2 and maximum $681.20 \mathrm{~mL}$ ) and gives Bell shape curve (Fig. 5). In batch digester a sharp increase in biogas production is recorded from $6^{\text {th }}$ to $7^{\text {th }}$ day and between $9^{\text {th }}$ and $11^{\text {th }}$ day and thereafter from $80^{\text {th }}$ day the biogas production continuously decreased. High temperature favours the biogas production ${ }^{4}$ and it decreases at low temperature.

Amount of produced biogas is not much important as its methane content because it is the utilizable part of biogas. Data presented in Table- 2 reveals that produced biogas in continuous and batch digestion process contains more or less similar amount of methane in it. So in this aspect there is no difference between these two processes. Initially lower methane content in batch digestion than continues digestion and then with time it goes more or less similar in both were also reported ${ }^{5}$.

\section{CONCLUSION}

Results of the study conclude that Human Excreta alone can be digested anaerobically to produce more than $300 \mathrm{~mL}$ biogas per day with more than $67 \%$ methane content either batch or continuous digestion process, continuous digestion process is more favorable for continuous and constant biogas production.

\section{ACKNOWLEDGMENTS}

The authors are grateful to the Gujarat State Biotechnology Mission (GSBTM FAP 201516, Project ID-1469), Gandhinagar, Gujarat for financial support for this study.

\section{REFERENCES}

1. United Nations, World Population Ageing 2013. Department of Economic and Social Affairs Population Division, New York.

2. Dahunsi, S. O, and Oranusi, U. S. Co-digestion of Food Waste and Human Excreta for Biogas Production. British Biotechnology Journal, 2013; 3(4): 485-499.

3. Mahanta, P, Saha, U. K, Dewan, A, Kalita, P, and Buragohain, B. Biogas Digester: A Discussion on Factors Affecting Biogas Production and Field Investigation of a Novel Duplex Digester. Journal of the Solar Energy Society of India, 2005; 15(2): 1-12.

4. Pandey, P. K and Soupir, M. L. Impacts of Temperatures on Biogas Production in Dairy Manure Anaerobic Digestion Impacts of Temperatures on Biogas Production in Dairy Manure. International Journal of Engineering and Technology,2012; 4, 629-631.

5. Obiukwu, O. O, and Nwafor, M. Comparative evaluation of batch and continuous process biogas production from animal wastes. International Journal of Ambient Energy, 2017; 37 (1), 29-35. 